\title{
Are symptoms of depression and anxiety in nursing students associated with their sociodemographic characteristics?
}

\author{
Sintomas de depressão e ansiedade em graduandos de enfermagem são associados as suas \\ características sociodemográficas?
}

¿Los síntomas de depresión y ansiedad en estudiantes de enfermería están asociados a sus características sociodemográficas?

\section{Letícia da Silva Coelho' \\ ORCID: 0000-0002-8801-7100}

Ana Carolina Carraro Tony' ORCID: 0000-0003-0937-8360

Giovana Caetano de Araujo Laguardia' ORCID: 0000-0001-7558-5937

Kelli Borges dos Santos' ORCID: 0000-0001-8423-9147

Denise Barbosa de Castro Friedrich' ORCID: 0000-0002-3321-1707

Ricardo Bezerra Cavalcante' ORCID: 0000-0001-5381-4815

Fábio da Costa Carbogim' ORCID: 0000-0003-2065-5998

'Universidade Federal de Juiz de Fora. Juiz de Fora, Minas Gerais, Brazil.

How to cite this article: Coelho LS, Tony ACC, Laguardia GCA, Santos KB, Friedrich DBC, Cavalcante RB, et al. Are symptoms of depression and anxiety in nursing students associated with their sociodemographic characteristics? Rev Bras Enferm. 2021;74(Suppl 3):e20200503. https://doi.org/10.1590/0034-7167-2020-0503

Corresponding author: Fábio da Costa Carbogim E-mail: fabiocarbogim@gmail.com

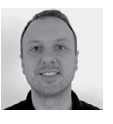

EDITOR IN CHIEF: Antonio José de Almeida Filho ASSOCIATE EDITOR: Álvaro Sousa

Submission: 07-04-2020

Approval: 09-27-2020

\begin{abstract}
Objective: to investigate symptoms of depression and anxiety and their association with the sociodemographic characteristics of undergraduate nursing students. Methods: a cross-sectional analytical study carried out with students from the Faculty of Nursing at Universidade Federal de Juiz de Fora from June to July 019. Data were collected through a sociodemographic questionnaire and the Beck Depression and Anxiety Inventories. Results: 192 students participated, with a mean age of $21.44( \pm 3.56)$ years. $85.93 \%$ of participants were female. The mean depression score was $22.40( \pm 12.35)$, and anxiety was $17.56( \pm 11.98)$. There was a difference in the mean of the scales for sex and psychotropic drugs $(p<0.05)$. Women presented moderate and severe classification for both scales. Severe symptoms prevailed among students from the $6^{\text {th }}$ to the $10^{\text {th }}$ semester $(18.22 \%)$. Conclusion: there was an association between depression and anxiety symptoms related to gender and psychotropic drugs.
\end{abstract}

Descriptors: Students, Nursing; Mental Health; Depression; Anxiety; Mental Disorders.

\section{RESUMO}

Objetivo: investigar sintomas de depressão e ansiedade e sua associação com as características sociodemográficas de estudantes da graduação em enfermagem. Métodos: estudo transversal analítico, realizado com estudantes da Faculdade de Enfermagem da Universidade Federal de Juiz de Fora, de junho a julho de 2019. Os dados foram coletados por questionário sociodemográfico e pelos Inventários de Depressão e Ansiedade de Beck. Resultados: participaram 192 estudantes com idade média de $21,44( \pm 3,56)$ anos. $O$ sexo feminino representou $85,93 \%$ dos participantes. A pontuação média de depressão foi $22,40( \pm 12,35)$, e ansiedade foi $17,56( \pm 11,98)$. Houve diferença na média das escalas para sexo e psicofármacos $(p<0,05)$. Mulheres apresentaram classificação moderada e severa para as duas escalas. A sintomatologia severa prevaleceu entre alunos do $6^{\circ}$ e $10^{\circ}$ semestre $(18,22 \%)$. Conclusão: houve associação entre sintomas de depressão e ansiedade relacionados às variáveis sexo e psicofármacos.

Descritores: Estudantes de Enfermagem; Saúde Mental; Depressão; Ansiedade; Transtornos Mentais.

\section{RESUMEN}

Objetivo: investigar los síntomas de la depresión y ansiedad y su asociación con las características sociodemográficas de los estudiantes de licenciatura en enfermería. Métodos: estudio analítico transversal, realizado con estudiantes de la Facultad de Enfermería de la Universidade Federal de Juiz de Fora, de junio a julio de 2019. Los datos se recolectaron mediante un cuestionario sociodemográfico e Inventario de Depresión y Ansiedad de Beck. Resultados: participaron 192 estudiantes con una edad promedio de $21,44( \pm 3,56)$ años. El sexo femenino representó el $85,93 \%$ de los participantes. La puntuación media de depresión fue $22,40( \pm 12,35)$ y la ansiedad fue $17,56( \pm 11,98)$. Hubo diferencia en la media de las escalas de sexo y psicofármacos $(p<0,05)$. Las mujeres presentaron clasificación moderada y grave para ambas escalas. Los síntomas severos prevalecieron entre los estudiantes de sexto y décimo semestre $(18,22 \%)$. Conclusión: hubo asociación entre síntomas de depresión y ansiedad relacionada con las variables sexo y psicofármacos.

Descriptores: Estudiantes de Enfermería; Salud Mental; Depresión; Ansiedad; Trastornos Mentales. 


\section{INTRODUCTION}

The end of adolescence and early adulthood is a phase marked by important transformations that signal a new cycle of possibilities, professional choice, financial independence and accountability for the acts of civil life ${ }^{(1)}$.

For many young adults, a major event in this cycle is entry into higher education, where they will be able to acquire the skills and abilities necessary for future professional performance ${ }^{(12)}$. On the other hand, this new phase may represent distancing from the family environment, high hours of study, social and leisure absences, in addition to competitiveness and demands for performance. Thus, these changes can lead to high physical and emotional investments, often related to mental disorders such as anxiety and depression ${ }^{(3)}$.

Anxiety is characterized as an emotional state of self-protection oriented towards the future, with physiological and behavioral responses directed to threatening situation ${ }^{(3-4)}$. It becomes pathological when prolonged and disproportionate to the stimulus, and can manifest itself through signs and symptoms such as tachycardia, changes in appetite, insomnia, irritability, sadness, lack of concentration, among others ${ }^{(4)}$. Depression, on the other hand, is referred to as multifactorial mood disorder, manifested, among other characteristics, by prolonged sadness, displeasure, feelings of guilt, sleep and appetite disorders, fatigue, cognitive difficulties and recurring ideas of self-extermination ${ }^{(3)}$.

The scientific literature highlights that psychiatric disorder prevalence among undergraduate students can be up to four times higher than the rates found in the general population ${ }^{(4-5)}$. Compatible with this information, research conducted at a Brazilian public university identified a high rate of anxiety and depression among undergraduate students, with a prevalence of $62.9 \%$ and $30.2 \%$, respectively ${ }^{(3)}$. Another investigation with nursing students from Brazil and Portugal highlighted that Brazilian undergraduate students were more prone to anxiety, depression and loss of emotional control(5). The authors did not identify factors directly related to this difference; however, they emphasize that institutional, environmental, cultural aspects and even satisfaction with academic life can influence psychological well-being and emotional balance ${ }^{(5)}$.

However, mental disorders have become emerging problems in the academy, with emphasis on anxiety and depression, which have a direct and profound impact on students' performance, feedback on low self-esteem, insecurity, concern and other feeling ${ }^{(5)}$. In the health field, when compared to other courses, undergraduate nursing students are additionally exposed to emotional overload related to patient safety, as they deal with the disease and terminality ${ }^{(1,3,6)}$.

A systematic review ${ }^{(7)}$ conducted to describe the triggering factors for psychological disorders in Brazilian undergraduate students in the health field, analyzed 18 investigations, of which only $22 \%$ addressed nursing students. Overall, dissatisfaction with the course, lack of emotional support, unsatisfactory performance, lack of leisure and course completion stood out as triggering factors ${ }^{(7)}$.

Thus, the knowledge gap that justifies the present investigation is related to the scarcity of publications related to symptoms of anxiety and depression in Brazilian nursing students and possible relationships with sociodemographic characteristics.

Therefore, it is necessary to know the magnitude of these disorders in higher education institutions and their specificities, as a way to establish the profile of students and outline strategies for prevention and health promotion.

\section{OBJECTIVE}

This study aimed to investigate symptoms of depression and anxiety and their association with the sociodemographic characteristics of undergraduate nursing students.

\section{METHODS}

\section{Ethical aspects}

This study met the ethical standards in research involving human beings. It was approved by the Research Ethics Committee with Human Beings at Universidade Federal de Juiz de Fora (UFJF).

\section{Design, place of study and period}

This is cross-sectional and analytical research that was guided by The Strengthening the Reporting of Observational Studies in Epidemiology (STROBE), aimed at cross-sectional investigations. The study was carried out at the Faculty of Nursing of UFJF, between June and July 2019.

\section{Population and sample: inclusion and exclusion criteria}

In the 2019 academic year, there were 308 students enrolled between the $1^{\text {st }}$ and $10^{\text {th }}$ semester. All students were invited by the researchers, through social networks and in the classroom, to participate in the investigation, being able to opt for receiving the access link through Google Forms or providing printed forms.

It was established as an inclusion criterion: to be a graduate student in nursing at UFJF, Brazil, regularly enrolled. Students who did not complete the data collection instruments and those who were away from the course for any reason were excluded.

For the sample calculation, the formula $n=N \cdot Z^{2} \cdot p \cdot(1-p) / Z^{2} \cdot p .(1-p) .+$ $e^{2}$. $(N-1)$ was used. " $\mathrm{N}$ "is the calculated sample; " $\mathrm{N}$ " is population; " $\mathrm{Z}$ " is the standardized normal variable associated with confidence level; " $P$ " is the true probability of the event; " $E$ " is sampling error, using a sampling error of $5 \%$ and a $95 \%$ confidence level. A sample size of 172 students was obtained. However, the authors preferred to exceed the minimum sample size, 192 students selected for convenience.

\section{Study protocol}

For data collection, the researchers used a sociodemographic questionnaire (with information on age, sex, race, income, religion, course period, leisure activities, alcohol and illicit drug use, psychotropic drug use) and the Beck Depression Inventory (BDI-II), Brazilian Portuguese version ${ }^{(8-9)}$ and Beck's Anxiety Inventory (BAI) ${ }^{(9)}$.

BDI-II ${ }^{(8-9)}$ contains 21 items, each with four answer options, among which participants choose the one most applicable to 
them to describe how they have been feeling in the last two weeks. These items refer to symptoms of depression, in increasing gradation, classified as absent, mild, moderate, and severe. Considering the sample from a non-clinical population, scores up to 13 were considered "minimal depression"; from 14 to 19 , "mild depression"; from 20 to 28, "moderate depression"; and from 29 to 63 , "severe depression".

Likewise, BAI consists of 21 items, with four response options, among which participants choose the one most applicable to them to describe how they have been feeling in the last two weeks. These items refer to symptoms of anxiety, in increasing gradation, classified as minimal, mild, moderate, and severe. Considering the sample from a non-clinical population, scores up to 10 were considered "minimal anxiety"; scores from 11 to 19, "mild anxiety"; scores from 20 to 30, "moderate anxiety"; and scores from 31 to 63 , "severe anxiety".

Considering that BDI-II and BAl questionnaires analyze complex psychic aspects, there was the participation of a professional psychologist who assisted in test acquisition, in interpretation of results and in management of serious cases with UFJF's psychology service.

\section{Analysis of results, and statistics}

The data were tabulated in Microsoft Excel ${ }^{\circ}$ and analyzed using the Stata software, version 15.0. A descriptive analysis of sociodemographic information included the calculation of frequency measures; and, for the scoring of the depression and anxiety scales, the measures of position and dispersion were calculated. The distribution normality of quantitative variables was verified by applying Shapiro-Wilk test. From the results, the difference of mean in the scales of depression and anxiety was verified by adopting Mann-Whitney test for dichotomous variables and the Kruskal-Wallis test for polytomous.

Based on framework ${ }^{(8-9)}$, the scores of the depression and anxiety scales were grouped into symptom levels. The presence of an association between these and participants' sociodemographic variables was verified by applying Fisher's exact test or Pearson's chisquare test. Throughout analysis, bilateral tests were adopted and 95\% significance level.

\section{RESULTS}

The study sample had 192 participants, whose mean age was 21.44 ( \pm 3.56 ) years. Thus, $85.93 \%$ of participants were women. White race was predominant $(56.77 \%)$, followed by mixed-race (25.52\%). Of the total, most (52.1\%) practiced physical exercise. Anxiolytic use was reported by $11.46 \%$, and $81.77 \%$ did not use any psychotropic drug (Table 1).
The mean score on the depression scale was 22.40 ( \pm 12.35$)$, while on the anxiety scale it was $17.56( \pm 11.98)$. As shown in Table 1 , a statistically significant difference $(p<0.05)$ was identified in the mean of the depression and anxiety scale, between sexes and psychotropic drug use. For variable sex, the highest mean on the scales was related to sex female and for variable psychotropic drugs, despite the lower amount, to students using antidepressants and mood stabilizers.

On the depression scale, severe symptoms were the most frequent $(30.73 \%)$, whereas on the anxiety scale, a minimal classification was predominant (30.21\%). On both scales, there was a statistically significant difference $(p<0.001)$ for symptom levels (Table 2).

Table 3 shows severe symptoms of depression being predominant $(28.13 \%)$ among female students, while minimal was the most frequent (6.77\%) in men. In students who were between the $1^{\text {st }}$ and the $5^{\text {th }}$ course's semester, minimal symptomatology was shown in most of them (16.67\%); between the $6^{\text {th }}$ and the $10^{\text {th }}$ semester, severe became predominant (18.22\%).

According to the symptoms identified in the anxiety scale, female students presented, in the majority, a moderate and severe classification (36.46\%); and male, minimal and light (10.42\%). Psychotropic drug use was associated with symptoms on this scale $(p<0.001)$.

Table 1 - Distribution of the total score of the scales by sociodemographic variables

\begin{tabular}{|c|c|c|c|c|c|}
\hline \multirow{2}{*}{ Variable } & \multirow{2}{*}{$\begin{array}{l}\text { Participants } \\
\text { (\%) }\end{array}$} & \multicolumn{2}{|c|}{ Depression Scale } & \multicolumn{2}{|c|}{ Anxiety Scale } \\
\hline & & $\begin{array}{l}\text { Mean } \\
(\text { SD)* }\end{array}$ & $\begin{array}{c}p \\
\text { value }^{\S \|}\end{array}$ & $\begin{array}{l}\text { Mean } \\
\text { (SD)* }\end{array}$ & $\underset{\text { value }^{\text {s॥ }}}{p}$ \\
\hline \multicolumn{6}{|l|}{ Sex } \\
\hline $\begin{array}{l}\text { Female } \\
\text { Male }\end{array}$ & $\begin{array}{l}165(85.93) \\
27(14.07)\end{array}$ & $\begin{array}{l}23.06(12.19) \\
18.40(12.78)\end{array}$ & $0.037^{\S}$ & $\begin{array}{l}18.06(11.69) \\
14.51(13.51)\end{array}$ & $0.049^{5}$ \\
\hline \multicolumn{6}{|l|}{ Race } \\
\hline Black & $31(16.15)$ & $25.32(13.48)$ & & $19.35(12.07)$ & \\
\hline Mixed-race & $49(25.52)$ & 22.91(12.59) & & 20.83(12.99) & \\
\hline Asian & $2(1.04)$ & 18.5(9.19) & $0.384^{\|}$ & $3(4.24)$ & $0.064^{\prime \prime}$ \\
\hline Indigenous & $1(0.52)$ & 35 & & 4 & \\
\hline White & $109(56.77)$ & $21.30(11.93)$ & & 15.97(11.16) & \\
\hline \multicolumn{6}{|l|}{ City } \\
\hline $\begin{array}{l}\text { Different from family's city } \\
\text { Same family's city }\end{array}$ & $\begin{array}{l}74(38.55) \\
118(61.45)\end{array}$ & $\begin{array}{l}23.25(12.83) \\
21.87(12.06)\end{array}$ & $0.53^{5}$ & $\begin{array}{c}18.28(12) \\
17.11(12.01)\end{array}$ & $0.471^{\S}$ \\
\hline \multicolumn{6}{|l|}{ Course semester } \\
\hline $\begin{array}{l}1 \text { st to } 5 \text { th } \\
6 \text { th to } 10 \text { th }\end{array}$ & $\begin{array}{l}98(51.04) \\
94(48.96)\end{array}$ & $\begin{array}{l}20.80(11.43) \\
24.07(13.09)\end{array}$ & $0.111^{\mathrm{s}}$ & $\begin{array}{l}15.74(10.18) \\
19.45(13.41)\end{array}$ & $0.091^{\S}$ \\
\hline \multicolumn{6}{|l|}{ Physicial activity } \\
\hline None & $92(47.92)$ & 20.93(12.37) & & $15.94(11.15)$ & \\
\hline Once a week & $67(34.90)$ & $22.91(11.76)$ & $0.149^{\|}$ & $18.88(13.50)$ & $0.188^{\prime \prime}$ \\
\hline Twice or more a week & $33(17.18)$ & $25.48(13.15)$ & & $19.39(10.62)$ & \\
\hline \multicolumn{6}{|l|}{ Use } \\
\hline Alcohol & $53(27.60)$ & $22.16(11.94)$ & & $16.75(11.04)$ & \\
\hline Cigarette/nicotine & $7(3.65)$ & $22.1(9.87)$ & & $21.3(12.90)$ & \\
\hline Marijuana & $2(1.04)$ & $25.5(6.36)$ & $0.819^{\prime \prime}$ & $27(2.82)$ & $0.336 "$ \\
\hline None & $130(67.71)$ & $22.45(12.61)$ & & $17.73(12.39)$ & \\
\hline \multicolumn{6}{|l|}{ Psychotropic drug } \\
\hline Antidepressant & $8(4.17)$ & $31.37(17.43)$ & & $29(13.84)$ & \\
\hline Anxiolytic & $22(11.46)$ & 18.90(11.14) & & 13(9.07) & \\
\hline Mood stabilizer & $3(1.56)$ & $42.66(10.06)$ & $0.036^{\prime \prime}$ & $38.33(22.47)$ & $0.016^{\| \prime}$ \\
\hline None & $157(81.77)$ & $22.13(11.80)$ & & $17.22(11.47)$ & 0.070 \\
\hline Other & $2(1.04)$ & $16(14.14)$ & & $17.5(3.53)$ & \\
\hline
\end{tabular}

Note: *Standard deviation; ${ }^{5}$ Mann-Whitney test; "Kruskal-Wallis test. 
Table 2 - Symptom level classification

\begin{tabular}{lcccc}
\hline $\begin{array}{l}\text { Symptom } \\
\text { levels }\end{array}$ & $\begin{array}{c}\text { Depression } \\
\text { Participants } \\
\text { (\%) }\end{array}$ & p value & $\begin{array}{c}\text { Anxiety } \\
\text { Participants } \\
\text { (\%) }\end{array}$ & p value \\
\hline Minimal & $57(29.69)$ & & $58(30.21)$ & \\
Mild & $31(16.14)$ & & $57(29.69)$ & \multirow{2}{*}{ (0.001" } \\
Moderate & $45(23.44)$ & $<\mathbf{0 . 0 0 1}^{\|}$ & $51(26.56)$ & \\
Severe & $59(30.73)$ & & $26(13.54)$ & \\
\hline
\end{tabular}

Note:"Kruskal-Wallis test.

\section{DISCUSSION}

Stimuli or events related to anxiety or depression symptoms in nursing students may or may not be linked to the academic environment ${ }^{(5)}$. Symptom manifestations involve cognitive, behavioral, physiological and emotional reactions that require individual assessment by a specialized professional ${ }^{(10)}$.

A statistically significant difference was identified in the mean of the scores for signs of depression and anxiety between the sexes and for people using psychotropic drugs. The scientific literature has described that, in addition to adaptive factors, the competitive educational environment and dealing with sick people, women are exposed to a greater proportion to specific variables that favor the development of disorders, such as cultural, social and hormonal fluctuations $^{(10-13)}$. In this regard, a meta-analysis ${ }^{(14)}$ highlighted the prevalence of psychiatric disorders among female students in the undergraduate nursing program, without, however, identifying the directly related variables, in addition to cultural and biological aspects. Therefore, more comparative studies are needed to examine the difference between the sexes and investigate the presence of specific factors and possible triggers of psychological disorders in this population ${ }^{(14)}$.

Concerning psychotropic drugs, although they act in changes in behavior, mood or other mental functions to improve or stabilize disorders, signs of depression and anxiety were found in people who use these medications, with emphasis on mood stabilizers and antidepressants. Even though there is no clear explanation in the context of this population, studies have described the high prevalence of self-medication in the health field, linked to incorrect medication use or inadequate dose for the alleged psychological changes ${ }^{(12,15-16)}$. On the other hand, an investigation identified that nursing students preferred to consult people close to them to seek specialized help for symptoms of mental disorders ${ }^{(17)}$. The belief in spontaneous resolution of the problem or the search for unskilled help
0

\begin{tabular}{|c|c|c|c|c|c|}
\hline Variable & Minimal (\%) & Mild (\%) & Moderate (\%) & Severe (\%) & $p$ value $^{\ddagger \|}$ \\
\hline \multicolumn{6}{|l|}{ Depression } \\
\hline \multicolumn{6}{|l|}{ Sex } \\
\hline Female & $44(22.92)$ & $27(14.07)$ & $40(20.83)$ & $54(28.13)$ & \multirow{2}{*}{$0.166^{\ddagger}$} \\
\hline Male & $13(6.77)$ & $4(2.08)$ & $5(2.60)$ & $5(2.60)$ & \\
\hline \multicolumn{6}{|l|}{ Race } \\
\hline Black & $7(3.65)$ & $4(2.08)$ & $7(3.65)$ & $13(6.77)$ & \multirow{5}{*}{$0.826^{\ddagger}$} \\
\hline Mixed-race & $15(7.81)$ & $6(3.13)$ & $13(6.77)$ & $15(7.81)$ & \\
\hline Asian & $1(0.52)$ & 0 & $1(0.52)$ & 0 & \\
\hline Indigenous & 0 & 0 & 0 & $1(0.52)$ & \\
\hline White & $34(17.71)$ & $21(10.94)$ & $24(12.50)$ & $30(15.62)$ & \\
\hline \multicolumn{6}{|l|}{ City } \\
\hline Different from family's city & $22(11.46)$ & $9(4.69)$ & $19(9.90)$ & $24(12.50)$ & \multirow[b]{2}{*}{$0.670^{\|}$} \\
\hline Same family's city & $35(18.23)$ & $22(11.46)$ & $26(13.54)$ & $35(18.22)$ & \\
\hline \multicolumn{6}{|l|}{ Course's semester } \\
\hline 1 st to 5 th & $32(16.67)$ & $19(9.90)$ & $23(11.98)$ & $24(12.50)$ & \multirow{2}{*}{$0.218^{\|}$} \\
\hline 6 th to 10 th & $25(13.02)$ & $12(6.25)$ & $22(11.46)$ & $35(18.22)$ & \\
\hline \multicolumn{6}{|l|}{ Physical activity } \\
\hline None & $32(16.67)$ & $17(8.85)$ & $18(9.38)$ & $25(13.02)$ & \multirow{3}{*}{$0.519^{\|}$} \\
\hline Once a week & $18(9.37)$ & $10(5.21)$ & $16(8.33)$ & $23(11.98)$ & \\
\hline Twice and more a week & $7(3.65)$ & $4(2.08)$ & $11(5.73)$ & $11(5.73)$ & \\
\hline \multicolumn{6}{|l|}{ Use } \\
\hline Alcohol & $16(8.34)$ & $7(3.65)$ & $15(7.81)$ & $15(7.81)$ & \multirow{4}{*}{$0.824^{\ddagger}$} \\
\hline Cigarette & 0 & $3(1.56)$ & $2(1.04)$ & $2(1.04)$ & \\
\hline Marijuana & 0 & 0 & $1(0.52)$ & $1(0.52)$ & \\
\hline none & $41(21.36)$ & $22(11.46)$ & $27(14.06)$ & $40(20.83)$ & \\
\hline \multicolumn{6}{|l|}{ Psychotropic drug } \\
\hline Antidepressant & $2(1.04)$ & $1(0.52)$ & $1(0.52)$ & $4(2.08)$ & \multirow{5}{*}{$0.205^{\ddagger}$} \\
\hline Anxiolytic & $10(5.21)$ & $1(0.52)$ & $7(3.65)$ & $4(2.08)$ & \\
\hline Mood stabilizer & 0 & 0 & 0 & $3(1.56)$ & \\
\hline None & $44(22.92)$ & $29(15.11)$ & $36(18.75)$ & $48(25.00)$ & \\
\hline Other & $1(0.52)$ & 0 & $1(0.52)$ & 0 & \\
\hline Anxiety & & & & & \\
\hline Sex & & & & & \\
\hline Female & $46(23.96)$ & $49(25.52)$ & $48(25)$ & $22(11.46)$ & \\
\hline Male & $12(6.25)$ & $8(4.17)$ & $3(1.56)$ & $4(2.08)$ & $0.145^{f}$ \\
\hline Race & & & & & \\
\hline Black & $8(4.17)$ & $7(3.65)$ & $11(5.73)$ & $5(2.60)$ & \\
\hline Mixed-race & $12(6.25)$ & $14(7.29)$ & $14(7.29)$ & 9 (4.69) & \\
\hline Asian & $2(1.04)$ & 0 & 0 & 0 & $0.572^{\ddagger}$ \\
\hline Indigenous & $1(0.52)$ & 0 & 0 & 0 & \\
\hline White & $35(18.23)$ & $36(18.75)$ & $26(13.54)$ & $12(6.25)$ & \\
\hline City & & & & & \\
\hline Different from family's city & $20(10.42)$ & $22(11.46)$ & $22(11.46)$ & $10(5.21)$ & \\
\hline Same family's city & $38(19.79)$ & $35(18.23)$ & $29(15.10)$ & $16(8.33)$ & $0.835^{\|}$ \\
\hline Course's semester & & & & & \\
\hline 1 st to 5 th & $32(16.67)$ & $31(16.15)$ & $25(13.02)$ & $10(5.21)$ & \\
\hline 6 th to 10 th & $26(13.54)$ & $26(13.54)$ & $26(13.54)$ & $16(8.33)$ & $0.497^{\| \prime}$ \\
\hline Physical activity & & & & & \\
\hline None & $34(17.71)$ & $24(12.50)$ & $23(11.98)$ & $11(5.73)$ & \\
\hline Once a week & $17(8.85)$ & $24(12.50)$ & $15(7.81)$ & $11(5.73)$ & $0.322^{\ddagger}$ \\
\hline Twice or more a week & $7(3.65)$ & 9 (4.69) & $13(6.77)$ & $4(2.08)$ & \\
\hline Use & & & & & \\
\hline Alcohol & $15(7.81)$ & $19(9.90)$ & $11(5.73)$ & $8(4.17)$ & \\
\hline Cigarette & $2(1.04)$ & $3(1.56)$ & $2(1.04)$ & 0 & \\
\hline Marijuana & 0 & 0 & $2(1.04)$ & 0 & $0.442^{\ddagger}$ \\
\hline None & $41(21.35)$ & 35 (18.23) & 37 (19.27) & $17(8.86)$ & \\
\hline Psychotropic drug & & & & & \\
\hline Antidepressant & $1(0.52)$ & $1(0.52)$ & $2(1.04)$ & $4(2.08)$ & \\
\hline Anxiolytic & $1(0.52)$ & $8(4.17)$ & $4(2.08)$ & $1(0.52)$ & \\
\hline Mood stabilizer & 0 & $1(0.52)$ & 0 & $2(1.04)$ & $0.033^{\ddagger}$ \\
\hline None & $50(26.05)$ & $48(25.00)$ & $46(23.96)$ & $21(10.94)$ & 0.035 \\
\hline Other & 0 & $1(0.52)$ & $1(0.52)$ & 0 & \\
\hline
\end{tabular}


increases the risk of underestimating important symptoms and worsening of the condition ${ }^{(17-19)}$.

With regards to other psychoactive substance consumption, there was a prevalence of alcohol, followed by nicotine and marijuana. However, the frequencies were lower than a similar study carried out with psychology students from northeastern Brazil, which identified alcohol consumption in $43.97 \%$ of participants, followed by marijuana and cigarettes with $18.6 \%$ and $9.48 \%$, respectively ${ }^{(20)}$. A Spanish multicenter study carried out with 4381 nursing students identified that $29.7 \%$ were smokers, $11.5 \%$ used marijuana and men were more likely to use cigarettes and/or marijuana than women ${ }^{(21)}$. Despite the variation presented in the studies, the literature has highlighted the prevalence of high alcohol, nicotine and marijuana consumption among undergraduate students, but the socio-cultural, climatic or economic differences may be related to this variation ${ }^{(17,22-23)}$. An investigation carried out with 182 Brazilian nursing students identified that $56.6 \%$ had used alcohol in the last 30 days preceding the research, $11 \%$ were smokers, $54.5 \%$ had a mean level of nicotine dependence and $10.4 \%$ had already tried some illicit drug ${ }^{(19)}$.

Researches ${ }^{(23-24)}$ have considered undergraduate students as a risk group for psychoactive substance use, considering that they produce transient relief effects in the symptoms of psychological disorders. In undergraduate nursing, illicit substance use has been linked to the search for relaxation, fun and pleasure ${ }^{(25)}$. On the other hand, the chronic use of these substances, especially alcohol, has been related to withdrawal syndromes, lack of concentration, reduced academic performance and exacerbation of symptoms of anxiety and depression ${ }^{(18-23,25)}$. Although there are few specific investigations for nursing students, psychoactive substances induce tolerance and dependence on increasing doses to achieve desired effects ${ }^{(19)}$.

The mean of signs of depression identified in the general population of undergraduate students has reached rates of $35 \%$ to $39 \%$, while anxiety reaches $18 \%$ to $24 \%{ }^{(26-27)}$. When analyzing the frequency of severe signs of depression and anxiety in relation to the semesters of the course, students who were between the $6^{\text {th }}$ and $10^{\text {th }}$ semester were the most affected. The frequency of minimal signs of depression and anxiety was more common among students from the $1^{\text {st }}$ to the $5^{\text {th }}$ semester. These data contrast with studies that describe a higher frequency of signs of severe psychological disorders in students of the first semesters, considering that adaptive and problem management strategies are more common to undergraduate students ${ }^{(6)}$.

When analyzing the frequency of severe signs of depression and anxiety in relation to the semesters of the course, students who were between the $6^{\text {th }}$ and $10^{\text {th }}$ semester were the most affected. The frequency of minimal signs of depression and anxiety was more common among students from the $1^{\text {st }}$ to the $5^{\text {th }}$ semester. These data contrast with studies that describe a higher frequency of signs of severe psychological disorders in students of the first semesters, considering that adaptive and problem management strategies are more common to undergraduate students ${ }^{(3,6,26-27)}$. On the other hand, when approaching the end of the course, the nursing student assumes greater responsibilities, clinical and managerial demands, based on which a gradual acquisition of autonomy is expected ${ }^{(28-29)}$. A research carried out with medical students states that the transitional process for professional life can also contribute to the increase of signs and symptoms of anxiety and depression ${ }^{(11)}$. A study developed with 1,538 Chinese nursing students reported high levels of stress and psychological morbidity in graduates of the course. The signs and symptoms were linked to late exposure to the clinical environment, combined with academic responsibilities and future professional expectations ${ }^{(30)}$.

Faced with tension processes and signs of psychological disorders, factors considered protective, such as leisure activities, physical exercise, support networks are important in emotional management ${ }^{(5,7,24,26)}$. It is worth mentioning that most research participants practiced physical exercises once or more during the week and reported living in the same city as the family. Investigations ${ }^{(29,31-32)}$ have described a higher prevalence of signs of depression and anxiety in undergraduate students who do not exercise, as well as those who have a precarious support network. Therefore, students who engage in regular physical exercise programs have shown higher levels of psychological well-being, relaxation, positive emotions and a lower incidence of severe anxiety and depression ${ }^{(17,33)}$. In this regard, universities play an important role in preventing depression, anxiety and other disorders by offering physical activity, social and psychological support programs.

\section{Study limitations}

The limitation of this research is the punctual assessment of symptoms of anxiety and depression, without monitoring the possible variations throughout the course. Moreover, the investigation focused on a single undergraduate nursing course.

\section{Contributions to nursing and health}

This study contributes with data that support new research, coping strategies and support for undergraduate students, as it signals vulnerabilities responsible for the symptoms of depression and anxiety. Among the strategies for promotion and prevention at universities, the offer of physical activity, social and psychological support programs stand out.

\section{CONCLUSION}

It was possible to identify that the symptoms of depression and anxiety in nursing students were associated with female gender and psychotropic drug use. We identified symptoms of anxiety and depression in both sexes; however, for female students, severe symptoms of depression were predominant; in those of males, minimal was the most frequent. In students between the $6^{\text {th }}$ and $10^{\text {th }}$ semester, severe symptoms figured prominently.

We highlight the importance of longitudinal studies that allow to deepen the understanding of the signs of depression and anxiety throughout nursing graduation as well as systematic reviews that summarize the evidence in this field.

\section{ACKNOWLEDGMENT}

We would like to thank UFJF for financing this research. 


\section{REFERENCES}

1. Cunningham S, Duffy A. Investing in our future: importance of postsecondary student mental health research. Can J Psychiatry. 2019;64(2):79-81. https://doi.org/10.1177/0706743718819491

2. Negash A, Khan MA, Medhin G, Wondimagegn D, Araya M. Mental distress, perceived need, and barriers to receive professional mental health care among university students in Ethiopia. BMC Psychiatry. 2020;20:187. https://doi.org/10.1186/s12888-020-02602-3

3. Fernandes MA, Vieira FER, Silva JS, Avelino FVSD, Santos JDM. Prevalence of anxious and depressive symptoms in college students of a public institution. Rev Bras Enferm. 2018;71(suppl 5):2169-75. https://doi.org/10.1590/0034-7167-2017-0752

4. Facioli AM, Barros ÂF, Melo MC, Ogliari ICM, Custódio RJM. Depression among nursing students and its association with academic life. Rev Bras Enferm. 2020;73(1):e20180173. https://doi.org/10.1590/0034-7167-2018-0173

5. Vieira MTS, Lessa IS, Luiz FS, Santos KB, Matos FAPS, Carbogim FC. Distress and psychological well-being of undergraduate nursing students from Brazil and Portugal. Rev Enferm Cent-Oeste Min. 2019;9:e3453. https://doi.org/10.19175/recom.v9i0.3453

6. Silva RM, Costa ALS, Mussi FC, Lopes VC, Batista KM, Santos OP. Health alterations in nursing students after a year from admission to the undergraduate course. Rev Esc Enferm USP. 2019;53:e03450. https://doi.org/10.1590/s1980-220x2018008103450

7. Souza M, Caldas T, De Antoni C. Illness factors of students in health area: a systematic review. Psicodebate. 2017;3(1):99-126. https://doi. org/10.22289/2446-922X.V3N1A8

8. Paranhos ME, Argimon IIL, Werlang BSG. Psychometric properties of the Beck Depression Inventory-II (BDI-II) in adolescents. Aval Psicol [Internet]. 2010[cited 2020 Apr 23];9(3):383-92. Available from: http://pepsic.bvsalud.org/scielo.php?script=sci_arttext\&pid=S1677-04712010000300005\&lng=pt

9. Cunha JA. Manual da versão em português das Escalas Beck. São Paulo: Casa do Psicólogo; 2001.

10. Milić J, Škrlec I, Vranješ IM, Podgornjak M, Heffer M. High levels of depression and anxiety among Croatian medical and nursing students and the correlation between subjective happiness and personality traits. Int Rev Psychiatr. 2019;31(7-8):653-60. https://doi.org/10.1080/095 40261.2019.1594647

11. Costa DS, Medeiros, NSB, Cordeiro RA, Frutuoso ES, Lopes JM, Moreira, SNT. Symptoms of depression, anxiety and stress in medical students and institutional coping strategies. Rev Bras Educ Méd. 2020;44(1):e040. https://doi.org/10.1590/1981-5271v44.1-20190069

12. Qriouet Z, Belaiche A, Qmichou Z, Cherrah Y, Sefrioui H. Benzodiazepines use in Morocco: a nationwide consumption database study between 2004 and 2017. Asian J Psychiatr. 2020;47:101852. https://doi.org/10.1016/j.ajp.2019.101852

13. Al Rasheed F, Naqvi AA, Ahmad R, Ahmad N. Academic stress and prevalence of stress-related self-medication among undergraduate female students of health and non-health cluster colleges of a public sector university in Dammam, Saudi Arabia. J Pharm Bioallied Sci. 2017;9(4):251-8. https://doi.org/10.4103/jpbs.JPBS_189_17

14. Tung YJ, Lo KKH, Ho RCM, Tam WSW. Prevalence of depression among nursing students: a systematic review and meta-analysis. Nurse Educ Today. 2018;63:119-29. https://doi.org/10.1016/j.nedt.2018.01.009

15. Alshahrani SM, Shaik AS, Alakhali KM, AI-Worafi YM, Bahamdan AK, Vigneshwaran E. Self-Medication Among King Khalid University Students, Saudi Arabia. Risk Manag Healthc Policy. 2019;(12):243-49. https://doi.org/10.2147/rmhp.s230257

16. Al-Shagawi MA, Ahmad R, Naqvi AA, Ahmad N. Determinants of academic stress and stress-related selfmedication practice among undergraduate male pharmacy and medical students of a tertiary educational institution in Saudi Arabia. Trop J Pharm Res. 2017;16(12):2997-3003 https://doi.org/10.4314/tjpr.v16i12.26

17. Zeng Y, Wang G, Xie C, Hu X, Reinhardt JD. Prevalence and correlates of depression, anxiety and symptoms of stress in vocational college nursing students from Sichuan, China: a cross-sectional study. Psychol Health Med. 2019;24(7):798-811. https://doi.org/10.1080/13548506.2019.1574358

18. Kılınç G, Aylaz R, Güneş G, Harmancı P. The relationship between depression and loneliness levels of the students at the faculty of health sciences and the factors affecting them. Perspect Psychiatr Care. 2020;56:431-438. https://doi.org/10.1111/ppc.12452

19. Sousa BOP, Souza ALT, Souza J, Santos Sivani A, Santos MA, Pillon SC. Nursing students: medication use, psychoactive substances and health conditions. Rev Bras Enferm. 2020;73(Suppl 1):e20190003. https://doi.org/10.1590/0034-7167-2019-0003

20. Barbosa L, Asfora G, Moura M. Anxiety and depression and psychoactive substance abuse in university students. SMAD Rev Eletr Saúde Mental Álcool Drog. 2020;16(1):1-8. https://doi.org/10.11606//issn.1806-6976.smad.2020.155334

21. Martínez C, Baena A, Castellano Y, Fu M, Margalef M, Tigova O, et al. Prevalence and determinants of tobacco, e-cigarettes, and cannabis use among nursing students: a multicenter cross-sectional study. Nurse Educ Today. 2019; 74:61-8. doi:10.1016/j.nedt.2018.11.018

22. Romero-López AM, Portero-de-la-Cruz S, Vaquero-Abellán M. Effectiveness of a web platform on university students' motivation to quit smoking. Rev Latino-Am Enfermagem. 2020;28:e3318. https://doi.org/10.1590/1518-8345.3731.3318

23. Othman N, Ahmad F, El Morr C, Ritvo P. Perceived impact of contextual determinants on depression, anxiety and stress: a survey with university students. Int J Ment Health Syst. 2019; 13(17):1-9. https://doi.org/10.1186/s13033-019-0275-x

24. Mousa OY, Dhamoon MS, Lander S, Dhamoon AS. The MD blues: under-recognized depression and anxiety in medical trainees. PLos One. 2016;11(6):e0156554. https://doi.org/10.1371/journal.pone.0156554 
25. Pires PLS, Soares GT, Brito IE, Lima CA, Junqueia MAB, Pillon SC. Correlation of the use of psychoactive substances with signs of anxiety, depression and stress in nursing students. Rev Atenc Saúde. 2019;17(61):38-44. https://doi.org/10.13037/ras.vol17n61.6099

26. Zimmermann M, Chong AK, Vechiu C, Papa A. Modifiable risk and protective factors for anxiety disorders among adults: a systematic review. Psychiatr Res. 2019;285:112705. https://doi.org/10.1016/j.psychres.2019.112705

27. Ballester L, Alayo I, Vilagut G, Almenara J, Cebrià A I, Echeburúa E, et al. Accuracy of online survey assessment of mental disorders and suicidal thoughts and behaviors in Spanish university students. Results of the WHO World Mental Health-International College Student initiative. Plos One. 2019;5;14(9):e0221529. https://doi.org/10.1371/journal.pone.0221529

28. Hedley D, Uljarević M, Foley K-R, Rich-dale A, Trollor, J. Risk and protective factors underlying depression and suicidal ideation in Autism Spectrum Disorder. Depress Anxiety. 2018;35(7):648-657. https://doi.org/10.1002/da.22759

29. Berk Y, Kaplan A, Agaoglu SA. An analysis of depression, anxiety and stress levels of university students who do sports and do not. European J Physical Educ Sport. 2018;4(2):70-8. https://doi.org/10.5281/zenodo.1184665

30. Smith GD, Yang F. Stress, resilience and psychological well-being in Chinese undergraduate nursing students. Nurse Educ Today. 2017;49:90-5. doi:10.1016/j.nedt.2016.10.004

31. Lee E, Kim Y. Effect of university students' sedentary behavior on stress, anxiety, and depression. Perspect Psychiatr Care. 2019;55(2):164-9. https://doi.org/10.1111/ppc.12296

32. Flett G, Khan A, Su C. Mattering and psychological well-being in college and university students: review and recommendations for campusbased initiatives. Int J Ment Health Addiction. 2019;17:667-80. https://doi.org/10.1007/s11469-019-00073-6

33. Seedhom AE, Kamel EG, Mohammed ES, Raouf NR. Predictors of perceived stress among medical and nonmedical college students, Minia, Egypt. Int J Prev Med. 2019;10:107. https://doi.org/10.4103/ijpvm.IJPVM_6_18 